\title{
Renty sieciowe urzędu gminy - studium przypadku
}

\author{
Dr Marcin Flieger (iD \\ Akademia Wojsk Lądowych \\ imienia generała Tadeusza Kościuszki \\ Wydział Zarządzania
}

\section{Wprowadzenie}

Choć w ostatnich latach problematyka nurtu sieciowego jest coraz intensywniej eksplorowana, w dyskusji wciąż dominuje perspektywa organizacji z sektora prywatnego. Relatywnie niewiele uwagi poświęca się zagadnieniu inicjowania i rozwijania współpracy sieciowej przez organizacje publiczne, w tym instytucje samorządowe. Dlatego też w rozdziale pogłębiono problematykę nurtu sieciowego, jako podmiot badań przyjmując organizacje sektora publicznego. Na poziomie samorządowym podstawową jednostkę reprezentuje urząd gminy, a jednym z kluczowych wymiarów zwiększania skuteczności realizowania zadań jest umiejętność podejmowania współpracy z innymi organizacjami funkcjonującymi w regioniel. Stąd też nasuwa się fundamentalne pytanie dotyczącego korzyści osiąganych przez urząd gminy dzięki podejmowaniu współpracy o charakterze sieciowym. Korzyści te zostały zidentyfikowane z perspektywy paradygmatu renty ekonomicznej i utożsamione z poszczególnymi postaciami renty sieciowej. Zrozumienie charakteru rent czerpanych przez urząd gminy, z uwzględnieniem perspektywy dynamicznej, ukazującej osiąganie kolejnych poziomów dojrzałości we współpracy sieciowej, stanowi niezwykle ważny warunek odpowiedniego pogłębiania interakcji pomiędzy współpracującymi partnerami ${ }^{2}$, a w rezultacie zwiększenia sprawności świadczenia usług publicznych oraz tworzenia wartości publicznej.

Badania przeprowadzono z wykorzystaniem metody studium przypadku, podporządkowując się jej rygorowi metodologicznemu. Dobór metody wynika z przyjętych celów oraz etapu rozwoju wiedzy w analizowanym obszarze badawczym. Funkcjonowanie sieci międzyorganizacyjnych jest wciąż zjawiskiem stosunkowo nowym,

1 M. Furmankiewicz, Funkcjonalno-przestrzenne sieci wspótpracy samorzqdów lokalnych, „Studia Regionalne i Lokalne" 2002, nr 1(8), s. 12-13.

2 K. Sakai, N.H. Kang, International Strategic Alliances: Their Role in Industrial Globalization, OECD, DSTI/DOC 5/2000. 
które rozwija się dynamicznie i jest uwarunkowane wieloma zmiennymi. Istnieje potrzeba dogłębnej analizy, pozwalającej formułować propozycje cech i przebiegu danego zjawiska. Dlatego też przeprowadzono badania o charakterze interpretatywnym, umożliwiające głębokie zrozumienie fragmentu rzeczywistości, poznanie danego zjawiska w konkretnym kontekście ${ }^{3}$. Biorąc pod uwagę złożoność badanych zjawisk oraz bogactwo i różnorodność informacji - charakterystyczne dla studium przypadku - w ramach przeprowadzonej procedury zastosowano strategię triangulacji metod gromadzenia danych, do których zaliczono: analizę dokumentów regulujących funkcjonowanie organizacji oraz wywiad kwestionariuszowy ekspercki.

Badania zostały przeprowadzone $\mathrm{w}$ ramach projektu badawczego sfinansowanego z subwencji przyznanej przez Ministra Obrony Narodowej [111/WZA/64/DzS].

\section{Rodzaje renty sieciowej}

Sieci międzyorganizacyjne powstają dlatego, że ich uczestnicy dostrzegają możliwość osiągania unikalnej korzyści w tego typu układu. Kreowanie rent stanowi zatem jeden z głównych motywów budowania sieci ${ }^{4}$. Podstawowym rodzajem renty ekonomicznej ${ }^{5}$ osiąganej na poziomie sieci jest renta relacyjna, ponieważ sieć uzyskuje korzyść dzięki układowi relacji występujących między jej uczestnikami. Relacje te stanowią fundament kreowania i przechwytywania wartości ${ }^{6}$. W literaturze ten rodzaj korzyści utożsamiany jest z następującymi rentami: zasobową (ricardiańską), monopolistyczną (chamberlinowską), innowacyjną (schumpeteriańską), przedsiębiorczą, menedżerską, organizacyjną, rentą w rozumieniu Penrose.

Natomiast przyjmując podejście egocentryczne, z perspektywy węzła w sieci (w tym przypadku urzędu gminy), korzyści ze współpracy sieciowej należy utożsamić z poszczególnymi postaciami renty sieciowej. Jej istota odwołuje się do specyficznego postrzegania procesu tworzenia wartości - w ujęciu tradycyjnym organizacja powinna skupiać się na zasobach własnych, natomiast z perspektywy sieci jest ona splotem kontraktów, które stanowią główny obiekt doskonalenia7 . Biorąc pod

3 S. Chełpa, Metody badań problematyki kadrowej, [w:] T. Listwan (red.), Zarządzanie kadrami, Wydawnictwo C.H. Beck, Warszawa 2002.

4 E.W.K. Tsang, Motives for Strategic Alliance: A Resource-based Perspective, „Scandinavian Journal of Management" 1998, vol. 14/3, s. 207-221.

5 R. Amit, J.P. Schoemaker, Strategic assets and organizational rent, „Strategic Management Journal" 1993, no. 14/1, s. 33-46.

6 M. Najda-Janoszka, Dynamic Capability-Based Approach to Value Appropriation, Jagiellonian University Press, Krakow 2016.

7 J. Niemczyk, Renta sieciowa, [w:] R. Borowiecki, T. Rojek (red.), Kooperencja przedsiębiorstw w gospodarce rynkowej. Konkurencja - kooperacja - rozwój, Fundacja Uniwersytetu Ekonomicznego w Krakowie, Kraków 2013, s. 111. 
uwagę różne poziomy dojrzałości (rozwoju) sieci oraz różne konteksty funkcjonowania danej organizacji, w praktyce wyróżnia się kilka postaci renty sieciowej:

- rentę z tytułu niższych kosztów transakcyjnych i niższych kosztów hierarchii;

- rentę z tytułu uczestniczenia w sieci wartości;

- rentę z tytułu apropriacji wartości powstającej u innych uczestników sieci;

- rentę z tytułu sieciowego tworzenia i sieciowej dyfuzji wiedzy;

- rentę z tytułu zachodzących w sieci procesów konwergencji;

- rentę z tytułu kształtowania zdolności dynamicznych;

- efekt sieciowy.

Renta z tytułu niższych kosztów transakcyjnych i niższych kosztów hierarchii oznacza dwojakiego rodzaju oszczędności. Pierwsza powstaje dzięki kontraktowaniu sieciowemu, które zastępuje kontrakty zawierane w postaci umów jednorazowych. Druga z kolei wynika z ograniczenia kosztów hierarchii dzięki zastąpieniu hierarchii koordynacją sieciową. Co istotne, omawiana renta dotyczy jedynie korzyści wynikających ze zmniejszenia kosztów działania, pomijając możliwości generowania przez sieć nadwyżki powstającej na przykład w wyniku dodatkowego zwiększenia efektu organizacyjnego ${ }^{8}$.

Renta $\mathrm{z}$ tytułu uczestniczenia w sieci wartości dotyczy tworzenia wartości w układzie sieci wartości. Wartość w sieci powstaje dzięki efektowi synergii, wynikającemu z sumowania kluczowych zasobów i działań partnerów. Organizacja będąca węzłem w sieci współtworzy wartość dla całej sieci, jednocześnie kreując wartość własną.

Natomiast renta $\mathrm{z}$ tytułu apropriacji wartości powstaje poprzez zawłaszczanie ${ }^{9}$, w tym przypadku części lub całości korzyści wytworzonej przez pozostałych uczestników sieci. Organizacja podejmuje wysiłki, aby zawłaszczyć wartość innych podmiotów lub przechwycić (zatrzymać) wartość wytworzoną przez siebie ${ }^{10}$. Zawłaszczanie może odbywać się w sposób legalny (poprzez umowy współpracy, licencji, franczyzy, przejęć itp.) lub nielegalny (np. zawłaszczanie wiedzy niejawnej, poprzez działania oportunistyczne).

Kolejną korzyścią z przystąpienia do sieci międzyorganizacyjnej jest renta z tytułu tworzenia i dyfuzji wiedzy. Jest ona związana ze zdolnością sieci do kreowania

8 J. Niemczyk, Strategia: od planu do sieci, Wydawnictwo Uniwersytetu Ekonomicznego we Wroctawiu, Wrocław 2013.

9 W. Czakon, Strategia jako reguty zawtaszczania renty ekonomicznej, [w:] R. Krupski (red.), Zarządzanie strategiczne. Strategie organizacji, „Prace Naukowe Wałbrzyskiej Wyższej Szkoły Zarządzania i Przedsiębiorczości” 2010, s. 137-149.

10 M. Najda-Janoszka, Dynamic Capability-Based Approach..., s. 29-32. 
wiedzy niejawnej przez firmę-integratora oraz jej dyfuzji do innych węzłów ${ }^{11}$. Dyfuzja wiedzy następuje dzięki specyficznym cechom samej sieci i pojawia się głównie w sytuacji istotnych różnic w zasobach wiedzy między uczestnikami sieci. Ponadto należy podkreślić, że w sieci przepływy wiedzy mają charakter wielokierunkowy.

Renta z tytułu zachodzących w sieci procesów konwergencji odnosi się do tzw. efektu doganiania i oznacza, że organizacja mająca słabszą pozycję na rynku (ograniczone zasoby i kompetencje, mniejszy udział w rynku, niższe wskaźniki mikroekonomiczne), funkcjonując w sieci, rozwijałaby się szybciej niż pozostali uczestnicy sieci, posiadający lepszą pozycję, docelowo zbliżając się do poziomu ich rozwoju. W przypadku urzędu gminy, będącego częścią lokalnej sieci publicznej, zmniejszanie różnic może dotyczyć między innymi racjonalizacji struktury i procesów czy też zwiększania kompetencji menedżerów publicznych.

W przypadku sieci międzyorganizacyjnej renta $\mathrm{z}$ tytułu kształtowania zdolności dynamicznych postrzegana jest jako korzyść osiągana dzięki przynależności do sieci, która ma specyficzne cechy kształtujące warunki sprzyjające rozwojowi tych zdolności. Same zdolności dynamiczne w literaturze najczęściej definiowane są w dwojaki sposób. Po pierwsze - oznaczają umiejętność integrowania, budowania i rekonfigurowania wewnętrznych i zewnętrznych kompetencji w celu dostosowania się do szybko następujących zmian w środowisku organizacji ${ }^{12}$. Po drugie - mobilizowanie kompetencji dynamicznych oznacza zdolność do rutynowego rekonfigurowania bazy zasobowej poprzez sprawne pozyskiwanie, konfigurowanie, integrowanie i uwalnianie wiązki zasobów, niezbędnej do tworzenia wartości ${ }^{13}$. Tak więc zdolności dynamiczne to organizacyjne i strategiczne rutyny, które pozwalają na nowo konfigurować zasoby w odpowiedzi na zmianę warunków funkcjonowania ${ }^{14}$.

Natomiast efekt sieciowy (network effect, network externalities) polega na tym, że wraz ze wzrostem liczby uczestników sieci wzrasta korzyść dla wszystkich jej uczestników. Tak więc każdy nowy uczestnik tworzy dodatkową wartość dla całej sieci $^{15}$. Klasyczne rozumienie efektu sieciowego dotyczy perspektywy klienta, dla

11 K. Perechuda, Dyfuzja wiedzy, Wydawnictwo Akademii Ekonomicznej we Wrocławiu, Wroctaw 2005.

12 D.J. Teece, G. Pisano, A. Shuen, Dynamic Capabilities and Strategic Management, „Strategic Management Journal" 1997, no. 18/7, s. 509-533.

13 W. Czakon, Sieci w zarządzaniu strategicznym, Oficyna Wolters Kluwer business, Warszawa 2012.

14 K.M. Eisenhardt, J.A. Martin, Dynamic capabilities: What are they?, „Strategic Management Journal" 2000, no. 21, s. 1105-1121.

15 J. Church, N. Gandal, D. Krause, Indirect Network Effects and Adoption Externalities, „Review of Network Economics" 2008, no. 7/3, s. 337-338. 
którego wraz ze wzrostem liczby użytkowników danego dobra zwiększa się jego wartość. W kontekście tematyki prowadzonych badań rodzi się pytanie o występowanie analogicznego efektu sieciowego w odniesieniu do liczby węzłów w sieci. Chodzi tutaj o sytuację, w której wraz ze wzrostem liczby uczestników lokalnej sieci publicznej wzrasta wartość związana z byciem częścią sieci dla tych uczestników.

\section{Poziomy dojrzałości we wspótpracy sieciowej}

Budowanie optymalnej struktury sieci stanowi pewien proces składający się z etapów (poziomów), które prowadzą do osiągnięcia dojrzałości sieciowej16. Współpraca najczęściej inicjowana jest przez działania o charakterze koordynacyjnym. Na tym etapie więzi są luźne, często nieformalne, a wspólne działania nie generują znaczącego ryzyka. Organizacje mają szansę na bliższe poznanie się oraz zrozumienie potrzeb i obopólnych korzyści. Z czasem relacja ewoluuje i docelowo może osiągnąć stadium partnerstwa. Tutaj więzy stają się bliskie, ścisłe, a realizowane zadania są bardziej złożone i wiążą się z większym ryzykiem.

Biorąc powyższe pod uwagę, a także specyfikę funkcjonowania urzędu gminy, w badaniach przyjęto następujące cztery poziomy dojrzałości we współpracy sieciowej urzędu z organizacjami funkcjonującymi w regionie ${ }^{17}$ :

- informowanie;

- konsultowanie;

- wspólne projekty - inicjatywy lokalne o charakterze operacyjnym;

- partnerstwo strategiczne - ciągła współpraca oparta na wspólnej wizji i celach długoterminowych.

16 W.E. Baker, The network organization in theory and practice, [w:] N. Nohria, B. Eccles (red.), Network and Organizations, Harvard Business School Press, Boston 1992, s. 397-429.

17 M. Furmankiewicz, Funkcjonalno-przestrzenne sieci wspótpracy..., s. 12-15; K. Krajewski, J. Śliwa, Lokalna przedsiębiorczość w Polsce. Uwarunkowania rozwoju, Wydawnictwo Naukowe Wydziału Zarządzania Uniwersytetu Warszawskiego, Warszawa 2004; J. Cieślik, I. Kotadkiewicz, Wspieranie rozwoju przedsiębiorczości w aglomeracjach miejskich. Narzędzia i instrumenty wspótpracy jednostek samorzqdu terytorialnego ze społecznością przedsiębiorców na poziomie lokalnym, Stołeczne Forum Przedsiębiorczości, Warszawa 2014; B. Słomińska, Gmina w procesach stymulowania przedsiębiorczości, „Samorząd Terytorialny” 2007, nr 3, s. 19-33. 


\section{Studium przypadku}

Do studium przypadku przyjęto Urząd Miejski w Kościanie. Kluczowe kryterium doboru stanowiła jaskrawość przypadku ${ }^{18}$ - badaniu poddano urząd, który w sposób aktywny rozwija i umacnia współpracę o charakterze sieciowym. Dzięki temu uzyskano wiarygodne dane bazujące na realnych doświadczeniach na każdym poziomie dojrzałości we współpracy sieciowej.

Gmina miejska Kościan liczy ponad 23 tys. mieszkańców i jest zlokalizowana w województwie wielkopolskim, w powiecie kościańskim. Leży w niewielkiej odległości od dużej aglomeracji miejskiej (Poznań), jednocześnie ma bardzo dobrze rozwiniętą infrastrukturę komunikacyjną (bliskość autostrady A2 i drogi ekspresowej S5). W rezultacie jest atrakcyjnym miejscem do osiedlania się mieszkańców oraz lokalizowania działalności gospodarczej, w tym przez firmy międzynarodowe. Na terenie gminy zarejestrowanych jest 2831 podmiotów gospodarczych oraz 27 organizacji pozarządowych. Urząd gminy jest członkiem trzech związków i stowarzyszeń gmin (miast) oraz współpracuje z trzema miastami partnerskimi.

\section{Charakter osiąganych rent sieciowych}

\section{Renta z tytułu niższych kosztów transakcyjnych i niższych kosztów hierarchii}

Urząd Miejski w Kościanie osiąga ten rodzaj renty przede wszystkim dzięki redukcji kosztów transakcyjnych, które w tym przypadku dzielą się na koszty ex ante oraz koszty ex post. Pierwsze odnoszą się do wspólnego badania potrzeb klienta, któremu dedykowana jest usługa lub inny rezultat wspólnego projektu. Z kolei korzyść ex post dotyczy procesu zacieśniania więzi i bardziej precyzyjnej identyfikacji charakteru, oczekiwań oraz potrzeb partnera. W rezultacie przy realizacji kolejnych zadań lub projektów nie ma potrzeby przeprowadzania dogłębnej, całościowej analizy zbieżności celów i oczekiwań.

18 B. Flyvbjerg, Five Misunderstandings about Case Study Research, [w:] M. Savin-Baden, C. Howell Major (red.), Qualitative Research: The Essential Guide to Theory and Practice, Routledge, London - New York 2012, s. 165-166. 


\section{Renta z tytułu uczestniczenia w sieci wartości}

Badani wskazali, że wartość w sieci powstaje głównie dzięki efektowi synergii, wynikającemu z sumowania zasobów finansowych, lokalowych i sprzętowych. Na płaszczyźnie współtworzenia wartości dla całej sieci urząd postrzega swój wkład jako umożliwianie innym organizacjom korzystania z zasobów kontrolowanych przez niego. Natomiast wartością kreowaną dla siebie jest przede wszystkim uzyskanie możliwości delegowania niektórych usług (szczególnie zlecanie zadań organizacjom pozarządowym) oraz wzbogacenie oferty usług publicznych dedykowanych mieszkańcom gminy dzięki uzyskaniu dostępu do zasobów partnera i możliwości zlecania usług.

\section{Renta z tytułu sieciowego tworzenia i sieciowej dyfuzji wiedzy}

Współpraca sieciowa Urzędu Miejskiego w Kościanie z innymi podmiotami funkcjonującymi w regionie charakteryzuje się wielokierunkowym przepływem wiedzy. W rezultacie zidentyfikowano dwojakiego rodzaju korzyści z perspektywy urzędu - pierwsza to korzyść z tytułu pozyskiwania wiedzy od innych węzłów, druga $z$ tytułu dyfuzji wiedzy do innych węzłów. W pierwszym przypadku korzyść związana jest ze współpracą z innymi urzędami gmin i pozyskiwaniem wiedzy na temat sposobu organizowania jednostek podległych. Za szczególnie cenne uznano pozyskiwanie wiedzy z zakresu możliwości i uwarunkowań adaptowania rozwiązań procesowych. $Z$ kolei przekazywanie wiedzy do innych podmiotów dotyczy przede wszystkim współpracy z organizacjami pozarządowymi i związane jest $\mathrm{z}$ dyfuzją wiedzy na temat wymagań formalno-prawnych oraz zwiększania świadomości dotyczącej uwarunkowań pozyskania dotacji oraz realizowania zadań zleconych. Z punktu widzenia urzędu gminy docelową korzyść stanowi pozyskanie partnera merytorycznie przygotowanego do podjęcia współpracy i wspólnego realizowania zadań i projektów.

Niezwykle interesujące w kontekście analizy istoty renty osiąganej przez Urząd Miejski w Kościanie jest występowanie pewnego zjawiska związanego ze współpracą z miastami partnerskimi. Do niedawna urząd osiągał rentę, ucząc się od partnerów z zagranicy. Pozyskana wiedza dotyczyła sposobu organizowania życia mieszkańców oraz zwiększania jakości świadczonych usług. Jednak w ostatniej dekadzie pozycja urzędu się zmieniła, dzisiaj to urząd gminy w Kościanie stanowi swego rodzaju benchmark dla innych jednostek samorządowych. Zjawisko to widoczne jest szczególnie w ramach współpracy z urzędami zza wschodniej granicy. 


\section{Renta z tytułu zachodzących w sieci procesów konwergencji}

Należy podkreślić, że istnieje bezpośredni związek pomiędzy rentą z tytułu zachodzących w sieci procesów konwergencji a rentą z tytułu sieciowego tworzenia i sieciowej dyfuzji wiedzy. Polega on na tym, że dzięki współpracy urząd uczy się, w jaki sposób funkcjonują i realizują swoje zadania inne gminy (miasta), a wiedza ta pozwala na implementowanie usprawnień oraz nowych rozwiązań. $W$ rezultacie urząd zwiększa swoją sprawność zarówno w obszarze wewnętrznej organizacji, jak i zarządzania mieniem komunalnym i świadczenia usług publicznych.

\section{Renta z tytułu kształtowania zdolności dynamicznych}

Renta dotyczy dwóch rodzajów korzyści. Przede wszystkim realizowanie wspólnych projektów wiąże się z akcesją do wiedzy z zakresu integrowania i rekonfigurowania kompetencji w sieci. Umiejętność ta $\mathrm{z}$ kolei prowadzi do usprawnienia procesu pozyskiwania i integrowania zasobów przez urząd. Dla przykładu: urząd gminy w Kościanie współpracuje z Wielkopolskim Ośrodkiem Kształcenia i Studiów Samorządowych - dzięki temu pozyskuje wiedzę na temat sposobów dostosowywania procedur do zmieniających się przepisów prawa.

\section{Efekt sieciowy}

Mimo iż renta w postaci efektu sieciowego pojawia się dopiero na poziomie realizacji projektów operacyjnych oraz partnerstwa strategicznego, korzyść ta jest bardzo widoczna i występuje podczas współpracy z organizacjami reprezentującymi wszystkie sektory. W przypadku organizacji biznesowych oraz pozarządowych im większa ich liczba w lokalnej sieci publicznej, tym większe możliwości realizowania zadań przez urząd $\mathrm{w}$ wyniku synergii różnorodnych zasobów, które w innym wypadku pozostawałyby niedostępne. Zasoby materialne, wiedza oraz umiejętności partnerów przyczyniają się do bardziej skutecznego i sprawnego realizowania zadań oraz rozszerzania oferty usług publicznych. Natomiast powiększanie sieci o partnerów reprezentujących sektor publiczny pozwala głównie na obniżanie kosztów jednostkowych realizowanych wspólnie zadań i usług. W przypadku Urzędu Miejskiego w Kościanie przykładem jest chociażby międzygminny związek śmieciowy. W rezultacie współpracy podjętej przez kilka sąsiadujących gmin urząd w Kościanie znacznie obniżył koszty i zwiększył sprawność zagospodarowania odpadów komunalnych. 


\section{Renta z tytutu apropriacji wartości powstającej u innych uczestników sieci}

Należy podkreślić, że Urząd Miejski w Kościanie w ogóle nie czerpie renty z tytułu zawłaszczania wartości. Jest to związane ze specyfiką i rolą samego urzędu, który w ramach współpracy sieciowej realizuje zadania i projekty, których beneficjentami często są organizacje będące częścią sieci. Urząd (jako węzeł w lokalnej sieci publicznej) koncentruje się zatem nie tyle na konkurowaniu (a w jego ramach na zawłaszczaniu wartości), ile na budowaniu partnerstwa mającego na celu dbanie o dobro wspólne. Co więcej, istotny czynnik ograniczający możliwości potencjalnego zawłaszczania wartości stanowią jednoznaczne, sztywne regulacje prawne określające ramy funkcjonowania urzędu. Urząd postrzega siebie jako uczestnika sieci, w szczególnym stopniu dbającego o realizowanie wspólnych działań zgodnie z prawem, w sposób transparentny, na podstawie wysokich standardów etycznych. Dlatego też nie dostrzega ani możliwości, ani korzyści z apropriacji wartości od innych uczestników sieci.

\section{Ujęcie dynamiczne}

Koncentrując się na ukazaniu korzyści ze współpracy sieciowej, czerpanych na kolejnych poziomach dojrzałości, można wskazać, jakie korzyści dominują, a jakie czerpane są w stopniu ograniczonym. Charakter tych korzyści w perspektywie dynamicznej ukazano w tabeli 1.

Urząd Miejski w Kościanie przede wszystkim uzyskuje rentę z tytułu sieciowego tworzenia i sieciowej dyfuzji wiedzy, rentę z tytułu uczestniczenia w sieci wartości oraz rentę z tytułu niższych kosztów transakcyjnych. Korzyści te w literaturze zgodnie uznawane są za główne przyczyny podejmowania przez organizacje współpracy o charakterze sieciowym ${ }^{19}$. W przypadku renty $\mathrm{z}$ tytułu sieciowego tworzenia i sieciowej dyfuzji wiedzy przepływy mają charakter dwukierunkowy. Dla urzędu w Kościanie ważne jest zarówno pozyskiwanie wiedzy od partnerów, jak i możliwość dyfuzji wiedzy do innych węzłów w sieci. Co istotne, na pierwszym poziomie dojrzałości urząd czerpie wiedzę głównie od innych organizacji publicznych (przede wszystkim innych gmin), natomiast dyfuzja wiedzy następuje na poziomie konsultowania i skierowana jest do organizacji pozarządowych.

19 S. Vangen, C. Huxham, Introducing the Theory of Collaborative Advantage, [w:] S.P. Osborne (red.), The New Public Governance? Emerging Perspectives on Theory and Practice of Public Governance, Routledge, London 2010; M.A. Peteraf, The Cornerstones of Competitive Advantage: a Resource-based View, „Strategic Management Journal” 1993, no. 14/3, s. 179-191. 
Na dwóch najwyższych poziomach dojrzałości przepływy wiedzy mają charakter wielokierunkowy.

Tabela 1. Korzyści ze współpracy sieciowej w ujęciu dynamicznym

\begin{tabular}{|c|c|c|c|}
\hline \multicolumn{4}{|c|}{ Poziomy dojrzałości } \\
\hline Informowanie & Konsultowanie & Projekty operacyjne & $\begin{array}{l}\text { Partnerstwo } \\
\text { strategiczne }\end{array}$ \\
\hline $\begin{array}{l}\text { Korzyści dominujące: } \\
\text { • Pozyskiwanie } \\
\text { wiedzy od innych } \\
\text { urzędów gmin } \\
\text { - Efekt synergii } \\
\text { wynikający } \\
\text { z sumowania } \\
\text { zasobów wiedzy } \\
\text { i kompetencji } \\
\text { Korzyść ograniczona: } \\
\text { - Redukcja kosztów } \\
\text { transakcyjnych } \\
\text { ex ante (wspólne } \\
\text { badanie potrzeb } \\
\text { klienta) }\end{array}$ & $\begin{array}{l}\text { Korzyści dominujące: } \\
\text { - Dyfuzja wiedzy } \\
\text { do organizacji } \\
\text { pozarządowych } \\
\text { - Efekt synergii } \\
\text { wynikający } \\
\text { z sumowania } \\
\text { zasobów } \\
\text { niematerialnych } \\
\text { - Możliwość } \\
\text { delegowania zadań } \\
\text { i zwiększania oferty } \\
\text { usług publicznych } \\
\text { Korzyść ograniczona: } \\
\text { - Redukcja kosztów } \\
\text { transakcyjnych } \\
\text { ex ante }\end{array}$ & $\begin{array}{l}\text { Korzyści dominujące: } \\
\text { - Wielokierunkowy } \\
\text { przeptyw wiedzy } \\
\text { - Adaptowanie } \\
\text { rozwiązań pro- } \\
\text { cesowych } \\
\text { - Synergia różno- } \\
\text { rodnych zasobów } \\
\text { (niematerialnych } \\
\text { i materialnych) } \\
\text { Korzyści ograniczone: } \\
\text { - Usprawnienie we- } \\
\text { wnętrznej organi- } \\
\text { zacji funkcjonowa- } \\
\text { nia urzędu } \\
\text { - Umiejętność } \\
\text { integrowania } \\
\text { i rekonfigurowania } \\
\text { kompetencji w sieci } \\
\text { - Redukcja kosztów } \\
\text { transakcyjnych } \\
\text { ex post (znajomość } \\
\text { celów i oczekiwań } \\
\text { partnera) }\end{array}$ & $\begin{array}{l}\text { Korzyści dominujące: } \\
\text { - Wielokierunkowy } \\
\text { przeptyw wiedzy } \\
\text { - Efekt synergii } \\
\text { wynikający } \\
\text { z sumowania } \\
\text { różnorodnych } \\
\text { zasobów } \\
\text { - Tworzenie } \\
\text { warunków } \\
\text { do rozwoju } \\
\text { społeczno- } \\
\text { gospodarczego } \\
\text { Korzyści ograniczone: } \\
\text { - Usprawnienie } \\
\text { sposobu } \\
\text { zarządzania } \\
\text { mieniem } \\
\text { komunalnym } \\
\text { i świadczenia ustug } \\
\text { publicznych } \\
\text { - Zwiększenie } \\
\text { sprawności } \\
\text { w pozyskiwaniu } \\
\text { i integrowaniu } \\
\text { zasobów } \\
\text { przez urząd } \\
\text { - Redukcja kosztów } \\
\text { transakcyjnych } \\
\text { ex post }\end{array}$ \\
\hline
\end{tabular}

Źródło: badania własne.

Natomiast główna korzyść z tytułu uczestniczenia w sieci wartości wyraża się w osiąganiu efektu synergii wynikającego z sumowania zasobów. Dla Urzędu Miejskiego w Kościanie na poziomie informowania i konsultowania synergia dotyczy zasobów niematerialnych (wiedzy, kompetencji oraz doświadczenia osób reprezentujących różne sektory), z kolei na dwóch najwyższych poziomach również zasobów materialnych. Ponadto oprócz wartości kreowanej dla siebie wskazano na istotne znaczenie uczestniczenia w procesie współtworzenia wartości dla 
całej sieci. Wynika to z faktu, iż uczestniczenie w sieci pozwala urzędom zwiększać sprawność i jakość świadczenia usług publicznych, które z kolei realizowane są na rzecz całej społeczności, w tym podmiotów będących częścią sieci.

$\mathrm{Na}$ wszystkich poziomach dojrzałości urząd czerpie rentę z tytułu niższych kosztów, przy czym redukcja dotyczy zarówno kosztów transakcyjnych ex ante, jak i ex post. Pierwsze osiągane są na poziomie informowania i konsultowania i wynikają z połączenia wysiłków przy badaniu potrzeb klienta. Natomiast koszty ex post minimalizowane są dzięki wspólnemu integrowaniu i uwalnianiu wiązki zasobów na dwóch najwyższych poziomach dojrzałości. W rezultacie następuje redukcja kosztów jednostkowych realizacji zadań i projektów.

Trzy kolejne postaci rent sieciowych pojawiają się dopiero na dwóch najwyższych poziomach dojrzałości we współpracy sieciowej. Chodzi tutaj o rentę z tytułu zachodzących w sieci procesów konwergencji, rentę z tytułu kształtowania zdolności dynamicznych oraz efekt sieciowy. Istota tych korzyści została przedstawiona w pierwszej części studium przypadku. Syntetyzując, renty te przede wszystkim pozwalają na usprawnienie wewnętrznej organizacji urzędu, integrowanie i rekonfigurowanie zasobów, a w konsekwencji usprawnienie sposobu zarządzania mieniem komunalnym i świadczenia usług publicznych.

\section{Podsumowanie}

Głównym zamierzeniem autora było wypełnienie luki badawczej wyrażającej się niedostatkiem badań dotyczących charakteru korzyści osiąganych przez urząd gminy w ramach współpracy sieciowej z innymi podmiotami funkcjonującymi $\mathrm{w}$ regionie, $\mathrm{z}$ uwzględnieniem perspektywy dynamicznej odnoszącej się do osiągania kolejnych poziomów dojrzałości we współpracy. W rezultacie przeprowadzonych badań wykazano, że poddany analizie urząd gminy osiąga wiele postaci rent sieciowych, a ich charakter zmienia się wraz z osiąganiem kolejnych poziomów dojrzałości. Urząd uzyskuje głównie rentę z tytułu sieciowego tworzenia i sieciowej dyfuzji wiedzy, rentę z tytułu uczestniczenia w sieci wartości oraz rentę z tytułu niższych kosztów transakcyjnych. Korzyści te osiągane są na wszystkich poziomach dojrzałości, jednak ich charakter ulega modyfikacji. Natomiast trzy kolejne renty pojawiają się dopiero na dwóch najwyższych poziomach dojrzałości. Okazało się również, że urząd w ogóle nie uzyskuje korzyści z tytułu apropriacji wartości, co związane jest ze specyfiką funkcjonowania i rolą samego urzędu gminy w świadczeniu usług publicznych na rzecz mieszkańców i innych organizacji. Świadomość i rozumienie możliwości oraz uwarunkowań osiągania różnego rodzaju korzyści ze współpracy sieciowej stanowią fundament skutecznego budowania przewagi kooperacyjnej urzędu gminy. 
Należy podkreślić, że przedstawiona problematyka dotyczy nieeksplorowanych dotychczas obszarów dociekań naukowych, dlatego też przyjęta metoda i przeprowadzone badania miały na celu nie tyle całościowe ujęcie i dogłębne wyjaśnienie problemu, ile dostarczenie ważnych informacji na temat wybranych, kluczowych zagadnień związanych z rozwijaniem współpracy sieciowej przez urząd gminy. Ograniczoną możliwość generalizowania wyników należy traktować jako punkt wyjścia do dalszych dociekań naukowych. Uzasadnione jest stworzenie hipotez, które zostaną przetestowane z użyciem metod ilościowych. W pierwszej kolejności założenia powinny dotyczyć statystycznej weryfikacji charakteru i zakresu czerpania przez urzędy gmin poszczególnych postaci rent sieciowych.

\section{Bibliografia}

Amit R., Schoemaker J.P., Strategic assets and organizational rent, „Strategic Management Journal" 1993, no. 14/1, s. 33-46.

Baker W.E., The network organization in theory and practice, [w:] N. Nohria, B. Eccles (red.), Network and Organizations, Harvard Business School Press, Boston 1992, s. 397-429.

Chetpa S., Metody badań problematyki kadrowej, [w:] T. Listwan (red.), Zarzadzanie kadrami, Wydawnictwo C.H. Beck, Warszawa 2002, s. 352-360.

Church J., Gandal N., Krause D., Indirect Network Effects and Adoption Externalities, „Review of Network Economics" 2008, no. 7/3, s. 337-338.

Cieślik J., Koładkiewicz I., Wspieranie rozwoju przedsiębiorczości w aglomeracjach miejskich. Narzędzia i instrumenty wspótpracy jednostek samorzqdu terytorialnego ze społecznością przedsiębiorców na poziomie lokalnym, Stołeczne Forum Przedsiębiorczości, Warszawa 2004.

Czakon W., Sieci w zarzadzaniu strategicznym, Oficyna Wolters Kluwer business, Warszawa 2012.

Czakon W., Strategia jako reguty zawłaszczania renty ekonomicznej, [w:] R. Krupski (red.), Zarzadzanie strategiczne. Strategie organizacji, „Prace Naukowe Wałbrzyskiej Wyższej Szkoły Zarządzania i Przedsiębiorczości” 2010, s. 137-149.

Eisenhardt K.M., Martin J.A., Dynamic capabilities: What are they?, „Strategic Management Journal" 2000 , no. 21, s. 1105-1121.

Flyvbjerg B., Five Misunderstandings about Case Study Research, [w:] M. Savin-Baden, C. Howell Major (red.), Qualitative Research: The Essential Guide to Theory and Practice, Routledge, London - New York 2012, s. 165-166.

Furmankiewicz M., Funkcjonalno-przestrzenne sieci wspótpracy samorzqdów lokalnych, „Studia Regionalne i Lokalne" 2002, nr 1(8), s. 12-13.

Krajewski K., Śliwa J., Lokalna przedsiębiorczość w Polsce. Uwarunkowania rozwoju, Wydawnictwo Naukowe Wydziału Zarządzania Uniwersytetu Warszawskiego, Warszawa 2004.

Najda-Janoszka M., Dynamic Capability-Based Approach to Value Appropriation, Jagiellonian University Press, Krakow 2016.

Niemczyk J., Renta sieciowa, [w:] R. Borowiecki, T. Rojek (red.), Kooperencja przedsiębiorstw w gospodarce rynkowej. Konkurencja - kooperacja-rozwój, Fundacja Uniwersytetu Ekonomicznego w Krakowie, Kraków 2013, s. 111-117.

Niemczyk J., Strategia: od planu do sieci, Wydawnictwo Uniwersytetu Ekonomicznego we Wrocławiu, Wroctaw 2013. 
Perechuda K., Dyfuzja wiedzy, Wydawnictwo Akademii Ekonomicznej we Wrocławiu, Wroctaw 2005.

Peteraf M.A., The Cornerstones of Competitive Advantage: a Resource-based View, „Strategic Management Journal" 1993, no. 14/3, s. 179-191.

Sakai K., Kang N.H., International Strategic Alliances: Their Role in Industrial Globalization, OECD, DSTI/DOC 5/2000, Paris.

Stomińska B., Gmina w procesach stymulowania przedsiębiorczości, „Samorząd Terytorialny” 2007, nr 3, s. 19-33.

Teece D.J., Pisano G., Shuen A., Dynamic Capabilities and Strategic Management, „Strategic Management Journal" 1997, no. 18/7, s. 509-533.

Tsang E.W.K., Motives for Strategic Alliance: A Resource-based Perspective, „Scandinavian Journal of Management" 1998, vol. 14/3, s. 207-221.

Vangen S., Huxham C., Introducing the Theory of Collaborative Advantage, [w:] S.P. Osborne (red.), The New Public Governance? Emerging Perspectives on Theory and Practice of Public Governance, Routledge, London 2010, s. 163-184.

\section{Streszczenie}

Celem rozdziału jest ukazanie charakteru rent sieciowych czerpanych przez urzędy gmin, z uwzględnieniem osiągania przez nie kolejnych poziomów dojrzałości we współpracy sieciowej. Renty sieciowe stanowią główną korzyść ze współpracy sieciowej z perspektywy danego węzła i mogą być postrzegane jako wyznaczniki przewagi kooperacyjnej organizacji. Tak więc na wstępie autor zidentyfikował kluczowe korzyści charakterystyczne dla współpracy sieciowej. Na poziomie sieci korzyść utożsamiono z rentą relacyjną, z kolei w podejściu egocentrycznym, z perspektywy urzędu gminy stanowiącego węzeł w sieci, odniesiono ją do poszczególnych postaci renty sieciowej. Ponieważ analiza uwzględnia perspektywę dynamiczną, autor zidentyfikował poziomy dojrzałości we współpracy sieciowej. Rozważania te stanowiły podstawę do przeprowadzenia badań z wykorzystaniem metody studium przypadku. W jego ramach ukazano istotę rent sieciowych osiąganych przez urząd gminy, także w ujęciu dynamicznym. Wyniki badań umożliwiły sformułowanie wniosków dotyczących zakresu i charakteru czerpanych rent, co pozwala na dogłębne zrozumienie zjawiska, a w rezultacie świadome i skuteczne budowanie przewagi kooperacyjnej urzędu.

Słowa kluczowe: sieć międzyorganizacyjna, współpraca sieciowa, renty sieciowe, urząd gminy 
Network advantage for a commune - case study

\section{Abstract}

The main purpose of the article is to analyze the characteristics of network advantage gained by communes, including the dynamic perspective of achieving another levels of network cooperation maturity. Network advantage constitutes the main benefit from network cooperation for a knot and it can be perceived as a determinant of an organization's collaborative advantage. Thus, at the beginning the author identified key benefits typical for network cooperation, both at the network level and the knot level. As the scrutiny included a dynamic perspective, also the level of network cooperation maturity were identified. This theoretical background allowed carrying research in a form of a case study. It showed sorts of network advantage gained by the commune, as the network cooperation maturity increased. The results led to conclusions concerning the range and characteristics of achieved benefits, which allows thorough understanding of the phenomenon and more effective creation of a commune's collaborative advantage.

Keywords: interorganizational network, network collaboration, network advantage, commune 